\title{
Evaluation of aerosol distributions in the GISS-TOMAS global aerosol microphysics model with remote sensing observations
}

\author{
Y. H. Lee ${ }^{1}$ and P. J. Adams ${ }^{1,2}$ \\ ${ }^{1}$ Department of Civil and Environmental Engineering, Carnegie Mellon University, Pittsburgh, PA, USA \\ ${ }^{2}$ Department of Engineering and Public Policy, Carnegie Mellon University, Pittsburgh, PA, USA
}

Received: 14 August 200 - Published in Atmos. Chem. Phys. Discuss.: 18 September 2009

Revised: 8 February 2010 - Accepted: 11 Februaty 2010 - Published: 1 March 2010

\begin{abstract}
The Aerosol Optical Depth (AOD) and Angstrom Coefficient (AC) predictions in the GISS-TOMAS model of global aerosol microphysics are evaluated against remote sensing data from MODIS, MISR, and AERONET. The model AOD agrees well (within a factor of two) over polluted continental (or high sulfate), dusty, and moderate seasalt regions but less well over the equatorial, high sea-salt, and biomass burning regions. Underprediction of sea-salt in the equatorial region is likely due to GCM meteorology (low wind speeds and high precipitation). For the Southern Ocean, overprediction of AOD is very likely due to high sea-salt emissions and perhaps aerosol water uptake in the model. However, uncertainties in cloud screening at high latitudes make it difficult to evaluate the model AOD there with the satellite-based AOD. AOD in biomass burning regions is underpredicted, a tendency found in other global models but more severely here. Using measurements from the LBASMOCC 2002 campaign, the surface-level OC concentration in the model are found to be underpredicted severely during the dry season while much less severely for EC concentration, suggesting the low AOD in the model is due to underpredictions in OM mass. The potential for errors in emissions and wet deposition to contribute to this bias is discussed.
\end{abstract}

\section{Introduction}

Aerosols perturb the energy balance of the Earth-atmosphere system by scattering and absorbing solar and terrestrial radiation and by modifying cloud properties (e.g. Forster et al., 2007; Hansen et al., 2005). These changes caused by an-

Correspondence to: $\mathrm{Y}$. H. Lee

(yunhal@andrew.cmu.edu) thropogenic aerosols are termed the direct radiative forcing and indirect radiative forcing. Estimates of aerosol forcing mostly rely on computational modeling (e.g. Forster et al., 2007; Hansen et al., 2005; Kinne et al., 2003; Schulz et al., 2006) and contain significant uncertainties due to the challenges of representing aerosol microphysics, optical properties, and the spatial and temporal variability of aerosols. To gain confidence in their predictions, to characterize systematic weaknesses or biases, and to correct model deficiencies causing these weaknesses, the evaluation of aerosol models with observations is required. Measurements from ground and space help reduce these uncertainties (e.g. Hansen et al., 2005; Kinne et al., 2003; Schulz et al., 2006).

Increasing availability of satellite measurements makes it possible to evaluate the spatial and temporal variability of aerosols in global models more effectively (e.g. Kinne et al., 2003, 2006; Liu et al., 2006; Schulz et al., 2006). Remote sensing observations by satellites provide relatively well characterized spatial and temporal distributions and capture the large-scale transport of aerosols that are not available from in-situ observations, making them especially useful for the evaluation of global aerosol models. A radiometer used in remote sensing measures radiances that are influenced by aerosols, air molecules, surface reflectance, and cloud reflectance; a central challenge in satellite remote sensing of aerosols is distinguishing aerosols from these other contributors to radiance. Satellite and ground-based remote sensing platforms complement each other. Satellite platforms provide global distribution while ground-based radiometers, such as AErosol RObotic NETwork (AERONET), avoid the problem of distinguishing between aerosol and surface reflectance. The MOderate Resolution Imaging Spectroradiometer (MODIS) and Multiangle Imaging SpectroRadiometer (MISR) provide AOD observations that have

Published by Copernicus Publications on behalf of the European Geosciences Union. 
frequently been used to evaluate global models (e.g. Kinne et al., 2003; Stier et al., 2005). Besides AOD, other aerosol optical and microphysical properties are also retrieved from radiometers but used more rarely due to lower confidence in data quality.

The AOD is a measure of light extinction in an atmospheric column. AOD is a spectrally dependent quantity, and a typical wavelength chosen for AOD is $500 \mathrm{~nm}$ or $550 \mathrm{~nm}$ because aerosols extinguish visible light effectively in the visible spectrum. The Angstrom coefficient (AC) describes the spectral dependence of AOD on the wavelength of light and provides important information about aerosol size. Aerosol single-scattering albedo is also retrieved by AERONET and measures the contribution of absorbing particles, mostly black carbon and dust particles, to AOD. Unlike AOD data, the uncertainty in the single-scattering albedo retrieved by AERONET is relatively high (i.e. within 0.03 for high aerosol loading with an optical thickness at $440 \mathrm{~nm}$ higher than 0.5 , while it increases to $0.05-0.07$ for lower aerosol optical thicknesses (Dubovik et al., 2000). These mass of these strongly absorbing components generally makes a weak contribution to CCN. Therefore, the SSA evaluation is not considered in this study.

Here we use remote sensing observations to evaluate the "GISS-TOMAS" model, a combination of the TwO-Moment Aerosol Sectional (TOMAS) aerosol microphysics model with the Goddard Institute for Space Studies General Circulation Model II-prime (GISS GCM II-prime). The goal of this study is to evaluate the GISS-TOMAS model against AOD data from MODIS, MISR and AERONET. Specifically, we seek to evaluate spatial and temporal distributions of aerosol AOD as well as aerosol size via the AC. The descriptions of the GISS-TOMAS model and observational datasets used for the model evaluation are given in Sect. 2. Evaluation of the model against satellite and ground-based data is presented in Sect. 3. Section 4 provides an overall discussion of the comparisons, and Sect. 5 gives summary and conclusions.

\section{Model description}

\subsection{Overview}

The GISS GCM II-prime has horizontal grid dimensions of $4^{\circ}$ latitude and $5^{\circ}$ longitude, with nine vertical sigma layers including the stratosphere to the $10 \mathrm{hPa}$ level (Hansen et al., 1983). A detailed description of the GISS GCM is found in Hansen et al. (1983). The parameterizations of convective and stratiform clouds are updated by Del Genio and Yao (1993) and Del Genio et al. (1996), respectively. The surface and boundary layer parameterization is improved by Hartke and Rind (1997), and the land-surface parameterization, e.g. surface air temperature and hydrological cycle over land, is improved by Rosenzweig and
Abramopoulos (1997). Chemical tracers are advected every hour by the model winds using a quadratic upstream scheme (Prather, 1986); heat and moisture are advected with a similar scheme. Monthly average of climatological sea surface temperatures data from Atmospheric Model Intercomparison Project (AMIP) (e.g. Gates et al., 1999) are prescribed in the model, and the daily values are determined by linear interpolation.

The TOMAS aerosol microphysics model uses a sectional approach that represents the aerosol size distribution by predicting the amount of aerosol in several size categories or "bins". TOMAS tracks two moments of the aerosol size distribution in each size bin: total aerosol number and mass. Total mass is decomposed into several aerosol species, allowing prediction of the size-resolved aerosol composition. The model has 30 size sections with the lower boundary of the smallest size bin being $10^{-21} \mathrm{~kg}$ dry mass, and each successive boundary has twice the mass of the previous boundary. This provides a size distribution that ranges approximately from $10 \mathrm{~nm}$ to $10 \mu \mathrm{m}$ in dry diameter, depending on aerosol density. TOMAS uses a moving sectional approach to treat water uptake; changes in water mass do not move particles between sections. Adams and Seinfeld (2002) provide a detailed description of the TOMAS model. The model tracks nine quantities for each size bin: sulfate mass, sea-salt mass, mass of pure (hydrophobic) elemental carbon (EC), mass of mixed (aged) EC, mass of hydrophobic organic matter (OM), mass of hydrophilic OM, mass of mineral dust, mass of water and the number of aerosol particles in that bin. In addition, the model tracks two bulk aerosol-phase species, methanesulfonic acid (MSA), and ammonium $\left(\mathrm{NH}_{4}^{+}\right)$, and five bulk gas-phase species: $\mathrm{H}_{2} \mathrm{O}_{2}, \mathrm{SO}_{2}$, dimethylsulfide (DMS), $\mathrm{H}_{2} \mathrm{SO}_{4}$, and ammonia $\left(\mathrm{NH}_{3}\right)$. For purposes of calculating condensation and coagulation rates, all aerosols are treated as internally mixed.

The TOMAS model used in this work includes previously developed modules for sulfate (Adams and Seinfeld, 2002), sea-salt (Pierce and Adams, 2006), and carbonaceous aerosols (Pierce et al., 2007), and mineral dust (Lee et al., 2009). Compared to the TOMAS model used in Lee et al. (2009), there are several modifications in the TOMAS model used in this work. These modifications are fully described in Sect. 2.2 of Pierce and Adams (2009a). Briefly, the pseudo-steady state assumption for sulfuric acid is assumed to solve the nucleation and condensation rates simultaneously (Pierce and Adams, 2009b), and the growth of nucleated particles up to the first size bin, a diameter of $10 \mathrm{~nm}$, is taken into account using the parameterization of Kerminen et al. (2004). The primary sulfate emission is assumed to be $1 \%$ of aerosol sulfur (instead of 3\%), and the size distribution of biofuel and biomass burning carbonaceous emission is changed such that the number mean diameter is now $100 \mathrm{~nm}$ instead of $30 \mathrm{~nm}$. Finally, the sub-grid coagulation of freshly emitted primary sulfate and carbonaceous particles is accounted for (Pierce et al., 2009). The descriptions 
Table 1. Globally and annually averaged aerosol budgets, burdens, and the comparison of column mass to AEROCOM column mass. *Note that, for sulfate, the units of sources and sinks are $\operatorname{Tg} \mathrm{S}$ per year and $\mathrm{Tg} \mathrm{S}$ for the burden.

\begin{tabular}{llllllll}
\hline Aerosols & $\begin{array}{l}\text { Total Sources } \\
{\left[\mathrm{Tg} \mathrm{yr}^{-1}\right]}\end{array}$ & $\begin{array}{l}\text { Dry Deposition } \\
{\left[\mathrm{Tg} \mathrm{yr}^{-1}\right]}\end{array}$ & $\begin{array}{l}\text { Wet Deposition } \\
{\left[\mathrm{Tg} \mathrm{yr}^{-1}\right]}\end{array}$ & $\begin{array}{l}\text { Burden } \\
{[\mathrm{Tg}]}\end{array}$ & $\begin{array}{l}\text { Lifetime } \\
{[\text { days }]}\end{array}$ & $\begin{array}{l}\text { Model Column mass } \\
{\left[\mathrm{mg} \mathrm{m}^{-2}\right]}\end{array}$ & $\begin{array}{l}\text { AEROCOM column mass } \\
{\left[\mathrm{mg} \mathrm{m}^{-2}\right]}\end{array}$ \\
\hline Sulfate* & 44 & 1.1 & 43 & 0.73 & 6.0 & 4.27 & 3.9 \\
Sea-salt & 7380 & 4740 & 2640 & 13.0 & 0.64 & 27.53 & 12.6 \\
Mixed EC & 1.6 & 0.25 & 7.61 & 0.14 & 7.0 & - & - \\
Pure EC & 6.4 & 0.13 & 0.01 & 0.03 & 1.5 & - & - \\
Total EC & 8.0 & 0.38 & 7.62 & 0.17 & 4.3 & 0.33 & -39 \\
Hydrophilic OM & 30.5 & 1.6 & 48.7 & 0.70 & 5.1 & - & - \\
Hydrophobic OM & 30.5 & 0.45 & 10.3 & 0.08 & 0.94 & - & 3.3 \\
Total OM & 61.0 & 2.0 & 59.0 & 0.78 & 3.5 & 1.55 & 39.1 \\
Dust & 2440 & 1900 & 560 & 17 & 2.6 & 37.1 & \\
\hline
\end{tabular}

Table 2. Aerosol densities, refractive indices (RI), and hygroscopic diameter growth factors. *The hygroscopic growth factor for OM applies only to hydrophilic OM.

\begin{tabular}{|c|c|c|c|c|c|c|c|c|}
\hline \multirow[t]{2}{*}{ Aerosol Type } & \multirow{2}{*}{$\begin{array}{l}\text { Density } \\
{\left[\mathrm{kg} \mathrm{m}^{-3}\right]}\end{array}$} & \multirow{2}{*}{$\begin{array}{l}\text { References } \\
\text { for density }\end{array}$} & \multirow{2}{*}{$\begin{array}{l}\text { Real } \\
\text { RI }\end{array}$} & \multirow{2}{*}{$\begin{array}{l}\text { Imaginary } \\
\text { RI }\end{array}$} & \multirow{2}{*}{$\begin{array}{l}\text { References } \\
\text { for RI }\end{array}$} & \multicolumn{3}{|c|}{ Hygroscopic growth factor } \\
\hline & & & & & & RH: $60 \%$ & RH: $80 \%$ & RH: $95 \%$ \\
\hline Sulfate & 1780 & Tang (1996) & 1.43 & $1.0 \mathrm{e}-8$ & Hess et al. (1998) & 1.20 & 1.39 & 2.02 \\
\hline Sea-salt & 2165 & Tang (1996) & 1.50 & $1.0 \mathrm{e}-8$ & Shettle and Fenn (1979) & 1.63 & 1.89 & 2.74 \\
\hline Elemental Carbon (EC) & 1800 & Bond and Bergstrom (2006) & 1.95 & 0.79 & Bond and Bergstrom (2006) & & - & \\
\hline Organic Matter (OM) & 1400 & Dick et al. (2000) & 1.53 & 0.006 & Shettle and Fenn (1979) & $1.15^{*}$ & $1.23^{*}$ & $1.31 *$ \\
\hline Dust & 2650 & Tegen and Fung (1994) & 1.56 & 0.006 & Torres et al. (2002) & & - & \\
\hline Water & 1000 & - & 1.33 & $1.96 \mathrm{e}-9$ & Hale and Querry (1973) & & - & \\
\hline
\end{tabular}

of wet deposition and dry deposition are available in Adams and Seinfeld (2002) and Lee et al. (2009). Briefly wet deposition is occurred in large-scale (stratiform) and convective clouds. For in-cloud scavenging, the modified Köhler theory is applied for the large-scale and convective clouds that are assumed to have a supersaturation of $0.2 \%$ and $1.0 \%$, respectively. Dry deposition uses the series resistance approach that treats a size-dependent gravitational settling of particles and a size-dependent resistance in the quasi-laminar sublayer. Table 1 presents a summary of annual global aerosol budgets and burdens for each aerosol component in this model simulation. Water uptake by sulfate, sea-salt, and hydrophilic $\mathrm{OM}$ is accounted for in the model. For sulfate and sea-salt, it uses a polynomial fit based on ISORROPIA, a thermodynamic equilibrium model for inorganic aerosols (Nenes et al., 1998). For organic carbon, it is based on the observations of Dick et al. (2000). Table 2 shows the hygroscopic growth factor of those aerosols at relative humidities of $60 \%, 80 \%$, and $95 \%$ (Note that $99 \%$ is the maximum relative humidity allowed in the model for aerosol water uptake).

\subsection{Aerosol optical depth module}

A module for AOD (aerosol optical depth) calculation has been developed for the GISS-TOMAS model. In this paper, the AOD calculations are performed "offline" based on monthly average model output. Here we provide a detailed description of the AOD calculation. Based on Mie theory, AODs at $550 \mathrm{~nm}$ (or $500 \mathrm{~nm}$ ) wavelength are calculated. Refractive indices and aerosol density used are selected from various references as shown in Table 1. Water uptake by sulfate, sea-salt, and organic aerosols is accounted for and is based on ISORROPIA results for sulfate and sea-salt and is based on observations of Dick et al. (2000) for organic carbon. In the global model, aerosol species are assumed to be internally mixed expect hydrophobic EC. The volume averaging method is applied to calculate the complex refractive index for the internally mixed aerosol particle including water. Optical properties are compiled into a lookup table, which is pre-calculated based on Mie theory. For each grid cell and size bin, particle composition is used to determine the volume-averaged refractive index, and optical properties are determined from the lookup table based on particle size and (mixed) refractive index. Based upon its concentration, the optical properties are used to calculate the contribution of that size bin and grid cell to column AOD. The column AOD is the sum of these contributions over all size bins in a grid cell and all cells in the column.

The AOD is calculated using the GISS-TOMAS model monthly average output, which provides aerosol size distributions and aerosol concentrations for every grid cell. As implemented here, the model AOD prediction is an offline 
Table 3. Locations of AERONET sites and corresponding measurement time periods.

\begin{tabular}{lllll}
\hline & Sites & Longitude & Latitude & Years \\
\hline 1 & Alta Floresta & $56.0^{\circ} \mathrm{W}$ & $9.9^{\circ} \mathrm{S}$ & $1999-2005$ \\
2 & Los Fieros & $60.6^{\circ} \mathrm{W}$ & $14.6^{\circ} \mathrm{S}$ & 1996 \\
3 & Cuiaba-Miranda & $56.0^{\circ} \mathrm{W}$ & $15.7^{\circ} \mathrm{S}$ & $2001-2005$ \\
4 & Mongu & $23.2^{\circ} \mathrm{E}$ & $15.2^{\circ} \mathrm{S}$ & $1995-2005$ \\
5 & Ilorin & $4.3^{\circ} \mathrm{E}$ & $8.3^{\circ} \mathrm{N}$ & $1998-2005$ \\
6 & Banizombou & $2.0^{\circ} \mathrm{E}$ & $13.0^{\circ} \mathrm{N}$ & $1995-2005$ \\
7 & Capo Verde & $22.9^{\circ} \mathrm{W}$ & $16.7^{\circ} \mathrm{N}$ & $1994-2004$ \\
8 & Bidi Bahn & $2.5^{\circ} \mathrm{W}$ & $14.1^{\circ} \mathrm{N}$ & $1996-1997$ \\
9 & Barbados & $59.5^{\circ} \mathrm{W}$ & $13.2^{\circ} \mathrm{N}$ & $1996-2000$ \\
10 & Sede Boker & $34.8^{\circ} \mathrm{E}$ & $30.9^{\circ} \mathrm{N}$ & $1998-2005$ \\
11 & Bahrain & $50.6^{\circ} \mathrm{E}$ & $26.2^{\circ} \mathrm{N}$ & $2004-2005$ \\
12 & Solar Village & $46.4^{\circ} \mathrm{E}$ & $24.9^{\circ} \mathrm{N}$ & $1999-2005$ \\
13 & Dalanzadgad & $104.4^{\circ} \mathrm{E}$ & $43.6^{\circ} \mathrm{N}$ & $1997-2005$ \\
14 & Yulin & $109.7^{\circ} \mathrm{E}$ & $38.3^{\circ} \mathrm{N}$ & $2001-2002$ \\
15 & Sevilleta & $106.9^{\circ} \mathrm{W}$ & $34.4^{\circ} \mathrm{N}$ & $1994-2005$ \\
16 & Cart site & $97.5^{\circ} \mathrm{W}$ & $36.6^{\circ} \mathrm{N}$ & $1996-2005$ \\
17 & Bondville & $88.4^{\circ} \mathrm{W}$ & $40.1^{\circ} \mathrm{N}$ & $1996-2005$ \\
18 & GSFC & $76.8^{\circ} \mathrm{W}$ & $39.0^{\circ} \mathrm{N}$ & $1995-2005$ \\
19 & Mexico city & $99.2^{\circ} \mathrm{W}$ & $19.3^{\circ} \mathrm{N}$ & $1999-2005$ \\
20 & Ispra & $8.6^{\circ} \mathrm{E}$ & $45.8^{\circ} \mathrm{N}$ & $2001-2005$ \\
21 & Kanpur & $80.3^{\circ} \mathrm{E}$ & $26.5^{\circ} \mathrm{N}$ & $2001-2005$ \\
22 & Shirahama & $135.4^{\circ} \mathrm{E}$ & $33.7^{\circ} \mathrm{N}$ & $2000-2005$ \\
23 & Bermuda & $64.7^{\circ} \mathrm{W}$ & $32.4^{\circ} \mathrm{N}$ & $1996-2005$ \\
24 & Lanai & $156.9^{\circ} \mathrm{W}$ & $20.7^{\circ} \mathrm{N}$ & $1996-2004$ \\
25 & Dry Tortugas & $82.9^{\circ} \mathrm{W}$ & $24.6^{\circ} \mathrm{N}$ & $1996-2003$ \\
26 & Tahiti & $149.6^{\circ} \mathrm{W}$ & $17.6^{\circ} \mathrm{S}$ & $1999-2005$ \\
27 & Rottnest Island & $115.5^{\circ} \mathrm{E}$ & $32.0^{\circ} \mathrm{N}$ & $2001-2004$ \\
28 & Nauru & $166.9^{\circ} \mathrm{E}$ & $0.5^{\circ} \mathrm{S}$ & $1999-2005$ \\
\hline & & & & \\
\hline
\end{tabular}

process and does not distinguish the cloud-free sky with the cloudy sky, while the remote sensing observations retrieve AOD only under the cloud-free (clear) sky. It is important to mention that the satellite retrieved data has limitations, including potential biases due to measurements in only clearsky conditions and the possibility of cloud contamination. Recent studies have sought to improve cloud screening algorithms and to try to retrieve aerosol properties near clouds (e.g. Brennan et al., 2005; Koren et al., 2007; Redemann et al., 2009; Twohy et al., 2009). The module calculates AOD at four wavelengths: $440 \mathrm{~nm}, 500 \mathrm{~nm}, 550 \mathrm{~nm}$, and $675 \mathrm{~nm}$. The $500 \mathrm{~nm}$ and $550 \mathrm{~nm}$ wavelengths are used to evaluate the model AOD with the AERONET and satellite measurements, respectively. The wavelengths of $440 \mathrm{~nm}$ and $675 \mathrm{~nm}$ are used to calculate an AC (Angstrom coefficient) that is evaluated with AERONET.

\subsection{Remote sensing observations}

AERONET is a worldwide federation of ground-based and automated Sun photometers that measure aerosol optical properties and precipitable water (Holben et al., 1998). Sunand sky-scanning CIMEL Sun photometers utilized in the AERONET program use $340,380,440,500,675,870$, and $1020 \mathrm{~nm}$ wavelength measurements to retrieve AOD (e.g. Holben et al., 1998). AERONET spectral AOD data, and by definition the $\mathrm{AC}$ as well, have been widely used as a standard for validating other remote sensing aerosol retrievals due to well characterized uncertainties in the AERONET measurements (e.g. Abdou et al., 2005; Kahn et al., 2005; Liu et al., 2004; Torres et al., 2002). However, column-integrated aerosol microphysical properties from AERONET have not been systematically evaluated against in-situ data (Kahn et al., 2004). In this paper, only $\mathrm{AOD}$ and $\mathrm{AC}$ are used. The data used in this work are monthly average AERONET Level 2.0 AOD. We selected 28 AERONET sites that represent the following characteristic regions: polluted continental, marine, biomass burning, and mineral dust-dominated. The AERONET site information is presented in Table 3. The following sites do not provide AOD at $500 \mathrm{~nm}$ : Banizoumbou, Barbados, Bidi Bahn, Capo Verde, and Yulin. For these sites, an AOD at $500 \mathrm{~nm}$ is estimated using AC obtained from AOD at 440 and $670 \mathrm{~nm}$. Where possible, we select sites providing multi-year measurement data, but some sites (Los Fieros and Yulin) do not provide this.

Terra, the first Earth Observing System satellite launched in December 1999, carries MODIS and MISR. MODIS has 36 spectral channels, covering the wavelength range from 0.405 to $14.385 \mu \mathrm{m}$ with a swath width of $2330 \mathrm{~km}$. It covers the globe in 1-2 days. In this paper, monthly average AOD level 3 (Collection 5) products, MOD08_M3.005, are used. A description of the Collection 5 algorithm is available online (Remer et al., 2008). One important change in the Collection 5 retrieval algorithm is a new surface reflectance parameterization for the over-land algorithm that improves a bias over bright land surfaces ( $\mathrm{Li}$ et al., 2005). MOD08_M3.005 is $1^{\circ}$ by $1^{\circ}$ resolution data measured for the time period 2000 to 2005 and are obtained from the Giovanni MODIS On-line Visualization and Analysis System website (http://acdisc.sci. gsfc.nasa.gov/Giovanni/modis/Terra.MOD08_M3.shtml). In some locations, e.g. bright land surfaces such as Saharan desert regions and snow/ice cover at the high latitudes and cloudy regions, Terra MODIS AOD data are not available due to failure of the retrieval process due to cloud or surface reflectance contamination.

MISR has four visible/near infra-red spectral bands (446, 557,671 , and $886 \mathrm{~nm}$ ) and nine cameras at discrete viewing angles and has a swath width of $360 \mathrm{~km}$ (Diner et al., 1998). Global coverage requires approximately 9 days but depends strongly on latitude: over 9 days at the equator and 2 days near the poles. In this work, we use monthly averaged MISR 
Level 3 retrieved AOD data, MIL3MAE, that is considered to be "Stage 2 Validated" in the MISR data quality description. According to the MISR Level 3 quality statements, the global Level 3 MISR aerosol products over Greenland and Antarctica (snow/ice fields) are currently being excluded due to low spatial contrast and also due to inadequate cloud screening. These data are obtained from the Giovanni MISR On-line Visualization and Analysis System website (http://g0dup05u. ecs.nasa.gov/Giovanni/misr.MIL3MAE.2.shtml). The MISR AOD data provided are $1^{\circ}$ by $1^{\circ}$ resolution data for the time period 2000 to 2005. Different angular information (e.g. radiation) measured in MISR is utilized to reduce surface reflection contamination and cloud screening and to identify the surface type (e.g. Di Girolamo and Wilson, 2003; Jin et al., 2002). However, similar to MODIS, surface reflection contamination is still a challenge in MISR as Kahn et al. (2005) shows the lowest correlation coefficient of MISR AOD and AERONET AOD over bright desert sites. Also, like MODIS, MISR AOD data over high latitude is either not available or more uncertain. Despite challenges over bright surfaces and cloudy regions, MODIS and MISR provide long-term global aerosol distributions that are very useful for global aerosol model evaluation.

Since the GCM meteorology is generic and does not correspond to any specific year, multiyear datasets are used for comparison to minimize biases that may be magnified by a single year observation. The AOD data from both remote sensing measurements have a finer resolution than the GISSTOMAS model. Therefore, the satellite retrieved AOD data in $1^{\circ}$ by $1^{\circ}$ resolution are averaged to obtain AOD on a $4^{\circ}$ by $5^{\circ}$ grid.

\section{Results}

\subsection{Global aerosol budgets}

Figure 1 shows the spatial distribution of column mass concentration $\left[\mathrm{mg} \mathrm{m}^{-2}\right]$ of each aerosol species including water and column aerosol number concentration $\left[\mathrm{m}^{-2}\right]$. To put these results in the context of other published global aerosol models, we compare our predicted column burdens to those from the AEROCOM global model intercomparison activity (Kinne et al., 2006). In Kinne et al. (2006), 20 global aerosol models reported speciated column masses. A subset of 15 global models is selected by eliminating 5 outliers including one model without AOD calculation and a multi-model and global average column mass is calculated for each species from these 15 models. Our column masses and these AEROCOM average values are compared in Table 1. All species in our model are within $\sim 20 \%$ of the AEROCOM averages, except OM and sea-salt, which differ by a factor of approximately two. Our model OM column mass $\left(1.55 \mathrm{mg} \mathrm{m}^{-2}\right)$ is half of the OM column mass (3.3 $\mathrm{mg} \mathrm{m}^{-2}$ ) in Kinne et al. (2006) and our model sea-salt
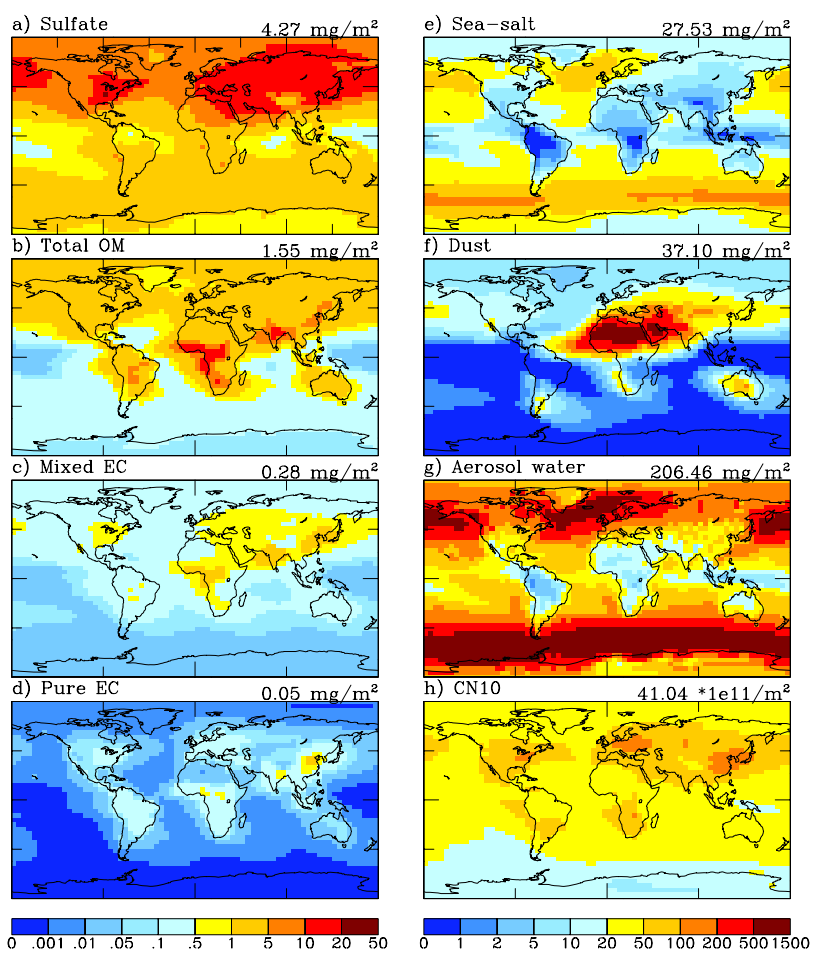

Fig. 1. Global distributions of annual-average aerosol column mass $\left[\mathrm{mg} \mathrm{m}^{-2}\right]$ and column number $\left[\mathrm{m}^{-2}\right]$. Values on the upper-right of each panel give global-average column mass and number concentrations.

column mass $\left(27.5 \mathrm{mg} \mathrm{m}^{-2}\right)$ is almost double the column mass $\left(12.6 \mathrm{mg} \mathrm{m}^{-2}\right)$ in Kinne et al. (2006). Note that Kinne et al. (2006) presents the results of the "EXPERIMENT A" simulations, which requests outputs from simulations with the model in its standard configuration.

\subsection{Evaluation against MODIS and MISR retrieved AOD}

Figure 2 shows the GISS-TOMAS model, MISR, and MODIS AOD global distributions for each season. Threemonth average in satellite retrieved data is obtained in each grid with available monthly average data. For example, when there is only one monthly average data available among the three months, the available data is used as the three-month average. However, when a grid cell does not have any available data due to the failure to retrieve AOD data from the satellite measurements, a grey color indicating no data available is shown in Fig. 2. Figure 2 illustrates several important features of the model AOD prediction as compared to satellite observations. First, the model AOD plume from North Africa is quite well predicted throughout the year except June to October. Second, compared to the two satellite retrievals, our model AOD is underestimated in biomass burning regions in South Africa and South America. MODIS and MISR observed a significant AOD (typically over 0.2) 

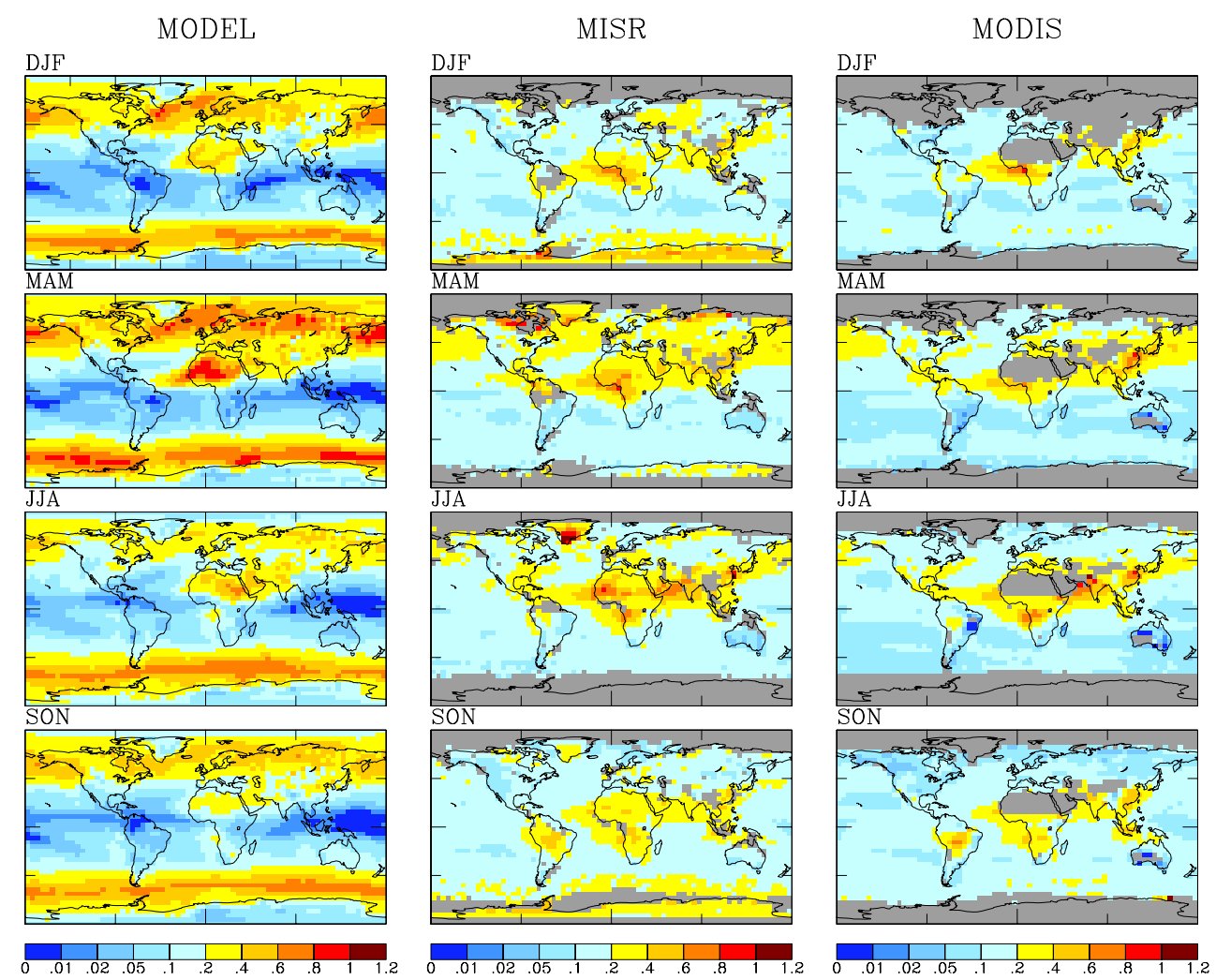

Fig. 2. Global distribution of AOD in the model, from MISR, and from MODIS in four seasons. Grey color in satellite observations indicates no data available. From top to bottom, the rows correspond to seasonal average AOD from December to February (DJF), March to May (MAM), June to August (JJA), and September to November (SON).

throughout the year, while the model shows very low AOD (less than 0.1). Third, an underestimation of AOD is observed along the equator especially in the Pacific Ocean and the Indian Ocean. Finally, the model predicts a high AOD in the Southern Ocean due to the presence of sea-salt.

To illustrate spatial trends in the comparison of model predictions to remote sensing measurements, the ratios of annual average model AOD to MODIS and MISR retrieved AODs are presented in Fig. 3. To get an annual-average MODIS/MISR retrieved AOD, we use the three-month average AOD data shown in Fig. 2. To avoid biases in the annual-average observed AOD, the averaging is only performed when a retrieved AOD is available in all four seasons. Otherwise, the annual-average is shown as "no data" with the grey color in Fig. 3. There is a strong latitudinal trend in model performance. Near the equator, the model tends to underestimate AOD compared to satellites, related to sea-salt from oceanic regions and carbonaceous aerosols from biomass burning regions. Conversely, the model tends to overpredict AOD compared to satellite data at high latitudes.
Figure 4 presents four scatter plots of annual-average model AOD versus MODIS and MISR retrieved AOD. These scatter plots are categorized by areas with high concentrations of a given species to diagnose the model AOD prediction biases. Column mass concentration is used to identify where an aerosol species is significant. High sulfate columns (called "polluted continental" regions) are those greater than $15 \mathrm{mg} \mathrm{m}^{-2}$; high OM columns (called "biomass burning" regions), greater than $5 \mathrm{mg} \mathrm{m}^{-2}$; high mineral dust columns, greater than $50 \mathrm{mg} \mathrm{m}^{-2}$; high sea-salt columns, greater than $50 \mathrm{mg} \mathrm{m}^{-2}$. Additionally, we define "moderate sea-salt" regions as those having sea-salt column mass concentrations between 20 and $50 \mathrm{mg} \mathrm{m}^{-2}$. High EC areas are mostly the same as high OM areas. In this scheme, it is possible for a model column to fall into more than one category. Also, we see from Fig. 1 that portions of India and China fall into the "biomass burning" category using this scheme. Table 4 presents the log-mean normalized bias (LMNB) and log-mean normalized error (LMNE) of each plot in Fig. 4, which are defined as follows:

$\mathrm{LMNB}=\frac{\sum_{i=1}^{N} \log _{10}\left(\frac{\mathrm{AOD}_{\bmod , i}}{\mathrm{AOD}_{\mathrm{obs}, i}}\right)}{N}$ 

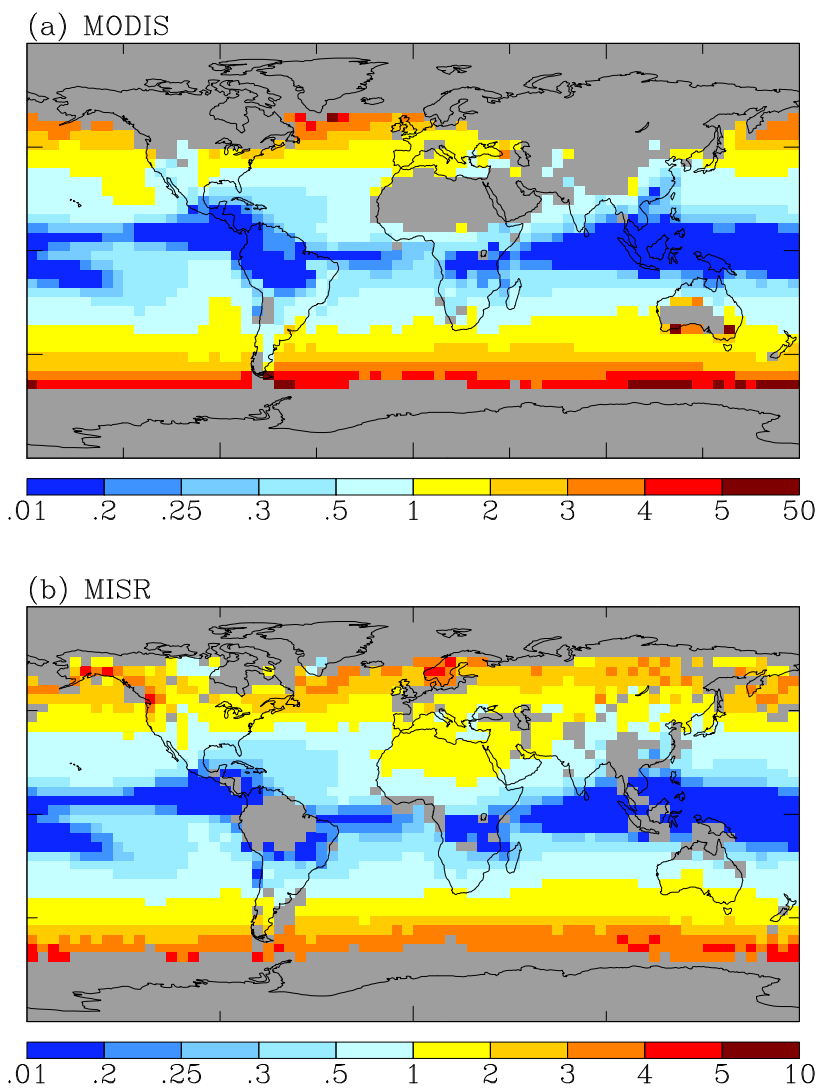

Fig. 3. Global maps of the ratio of annual-average AOD in the model prediction to (a) MODIS and (b) MISR AOD. Grey color indicates no data available from the satellite instrument.

$\mathrm{LMNE}=\frac{\sum_{i=1}^{N} \operatorname{abs}\left[\log _{10}\left(\frac{\mathrm{AOD}_{\bmod , i}}{\mathrm{AOD}_{\text {obs }, i}}\right)\right]}{N}$

where $\mathrm{AOD}_{\text {mod, } i}$ is the model-predicted $\mathrm{AOD}$ at site $i$ (i.e. corresponding grid cell), $\mathrm{AOD}_{\mathrm{obs}, i}$ is the retrieved $\mathrm{AOD}$ from remote sensing instruments at site $i$ (or corresponding grid cell for MODIS and MISR), and $N$ is the total number of observation sites.

From Fig. 4 and Table 4, we see that model AOD agrees with MODIS and MISR within a factor of two for dusty (high dust), polluted continental (high sulfate), and moderate sea-salt regions. However, consistent with finding above, model AOD in high OM regions is significantly underestimated, while that in high sea-salt region is significantly overestimated. For the high sea-salt region, the LMNB of 0.47 (MODIS) and 0.41 (MISR) indicates an average overestimation by a factor of 3.0 and 2.6, respectively. In the high OM region, the model systematically underpredicts AOD by a factor of 3 compared to MODIS and MISR.
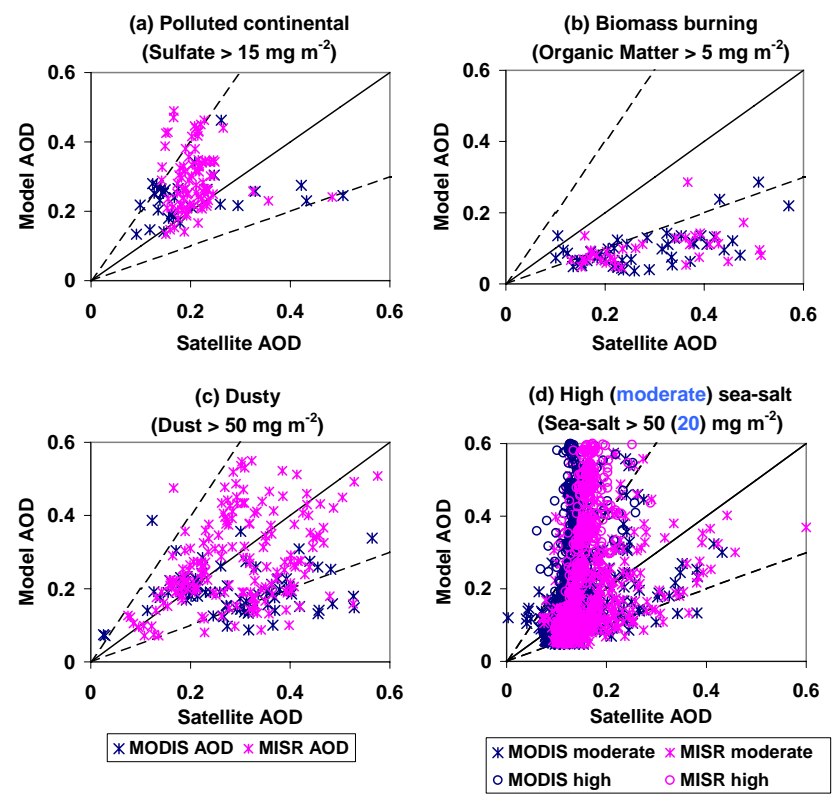

Fig. 4. Scatter plots of model-predicted AOD and satellite-retrieved AOD. The solid line and dashed lines are for 1:1 and 1:2 (or 2:1), respectively. In (a) to (d), MODIS and MISR AOD are presented as blue and pink, respectively. In panel (d), for high sea-salt areas, MODIS and MISR AOD are presented as circles.

Table 4. Log-mean normalized bias (LMNB) and log-mean normalized error (LMNE) of model-predicted AOD values compared with MODIS, MISR, and AERONET AOD observations.

\begin{tabular}{llrl}
\hline Observation & Pollution type & LMNB & LMNE \\
\hline MODIS & & -0.15 & 0.23 \\
MISR & Dusty region & -0.04 & 0.16 \\
AERONET & & -0.05 & 0.21 \\
\hline MODIS & \multirow{2}{*}{ Polluted continental region } & 0.11 & 0.19 \\
MISR & & -0.15 & 0.23 \\
AERONET & & -0.56 & 0.56 \\
MODIS & \multirow{2}{*}{ Biomass burning region } & -0.52 & 0.53 \\
MISR & & -0.62 & 0.62 \\
AERONET & & 0.47 & 0.47 \\
\hline MODIS & \multirow{2}{*}{ High sea-salt region } & 0.41 & 0.41 \\
MISR & \multirow{2}{*}{ Moderate sea-salt region } & -0.02 & 0.16 \\
\hline MODIS & -0.06 & 0.19 \\
MISR & Oceanic region & -0.43 & 0.44 \\
\hline AERONET & & & \\
\hline
\end{tabular}

\subsection{Evaluation against AERONET AOD and AC}

The geographical locations of the 28 AERONET sites are presented in Fig. 5. Figure 6 shows a scatter plot of annual-average AOD prediction and AERONET AOD at 28 


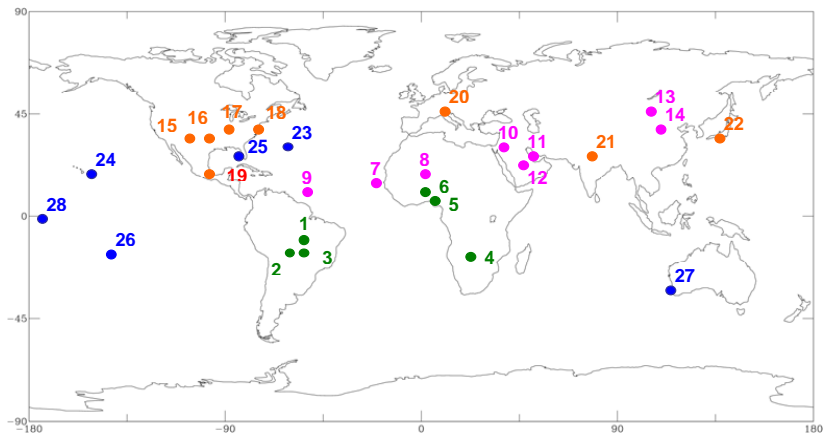

Fig. 5. Geographical location of 28 AERONET sites used in this work. Biomass burning sites are green, dust-dominated sites are pink, polluted continental sites are orange, and marine sites are blue. The site numbers correspond to those in Table 3.

measurement sites divided into four categories: biomass burning (green), dusty (pink), polluted continental (orange), and oceanic sites (blue). Table 4 shows the corresponding LMNB and LMNE for each regional category. Figure 7 shows temporal distributions of model AOD and AERONET AOD from January to December.

The model predictions are mostly underestimates in the biomass burning sites (1 to 6) and are more severe in South American sites (1, 2, and 3) and the South African site (4). Ilorin (5) and Banizoumbou (6) are also influenced by mineral dust aerosols, which may explain why they are better predicted than sites 1 to 4 , which are dominated by biomass burning. Model AOD is underestimated by a factor of 4.2 (LMNB: -0.62 ) on average for these sites. Excluding the two sites in North Africa where mineral dust is also transported (sites 5 and 6 ), the model AOD is underestimated by a factor of 7.2 (LMNB: -0.86). Possible causes of the underprediction are discussed in Sect. 4.

Most dusty sites (7 to 14, except 9) agree with AERONET AOD within a factor of two. The AOD in dusty regions is underpredicted by only $10 \%$ on average (LMNB: -0.05 ), and the model predictions are typically within a factor of 1.6 of observed values (LMNE: 0.21). In Fig. 7, dusty sites (7 to 14) agree well with AERONET except summer and autumn periods in regions influenced by Africa dust (sites 5 though 9).

All polluted continental sites (15 to 22) show good agreement except Mexico City (19), which is underpredicted by an order of magnitude. The AOD prediction in polluted continental sites is underestimated by a factor of 1.4 on average (LMNB: -0.15 ), and the model predictions are within a factor of 1.7 of observed values (LMNE: 0.23). Excluding Mexico City, the AOD predictions are better, with a LMNB of 0.95 and LMNE of 0.11 . The oceanic sites (23 to 28) are underpredicted, more severely near the equator (28). The AOD prediction in oceanic sites is underestimated by a factor of 2.7 on average (LMNB: -0.43 ), and the model predic-

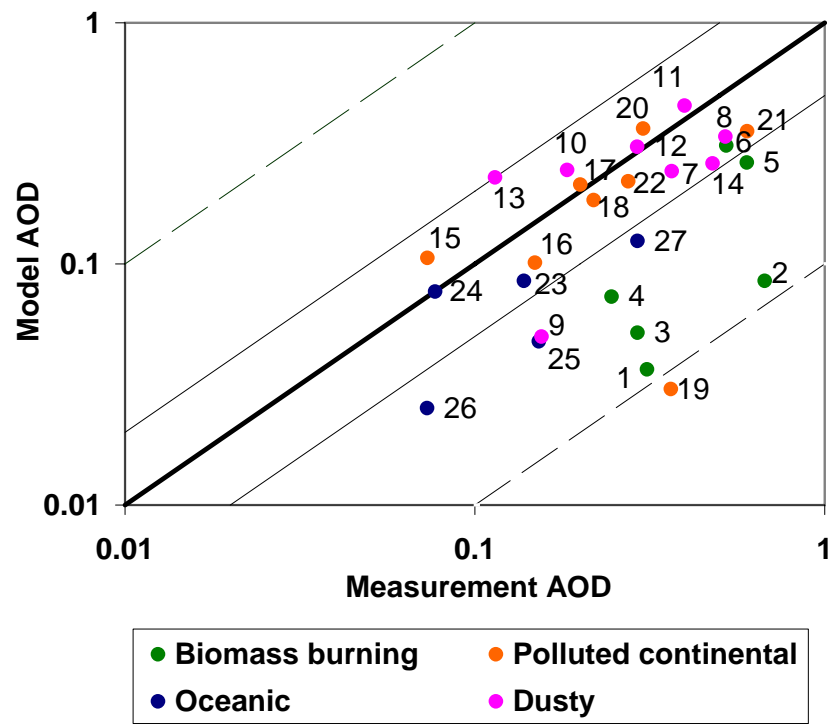

Fig. 6. Scatter plot of AOD from the model and AERONET. Biomass burning sites are green, dusty sites are pink, polluted continental sites are orange, and oceanic sites are blue. The thick and thin solid lines are for $1: 1$ and $2: 1$, respectively. The thin dashed line is for 10:1. The site numbers correspond to those in Table 3.

tions are within a factor of 2.8 of observed values (LMNE: 0.44). Bermuda (23) and Rottnest Island (27) are also influenced by other aerosol species, e.g. long-range transported mineral dust. Note that Nauru (28) is not shown in Fig. 6 because its model AOD (0.005) is very low. Without Nauru (28), which suffers from low wind speeds predicted by the model (see Section 4), the model prediction is within a factor of 2, consistent with good model prediction in moderate sea-salt region for the evaluation with MODIS and MISR.

Figure 8 displays seasonal cycles of monthly averaged model AC and AERONET AC. Higher AC $(>1)$ indicate an aerosol dominated by fine mode particles, while lower AC $(<1)$ indicate a substantial fraction of coarse mode particles (e.g. Holben et al., 2001). AERONET AC in biomass burning regions (1-4) is mostly above 1 throughout the year and is the highest during the dry season, the maximum biomass burning season. Model AC in Alta Floresta and Mongu is within the interannual variability of AERONET AC except the spring in Alta Floresta. Ilorin and Banizoumbou shows low $\mathrm{AC}$ during the spring and high $\mathrm{AC}$ during summer, which reflects the seasonal influences of mineral dust and biomass burning in those regions. Generally dusty sites have AC below 1 in the presence of mineral dust but the model underpredicts AC compared to AERONET for Capo Verde, Sede Boker, Bohrain, and Solar Village. Polluted continental sites show generally good agreement to AERONET, although the model AC tends to be slightly higher than observed. Oceanic sites, except Bermuda, tend to underpredict AERONET AC. 

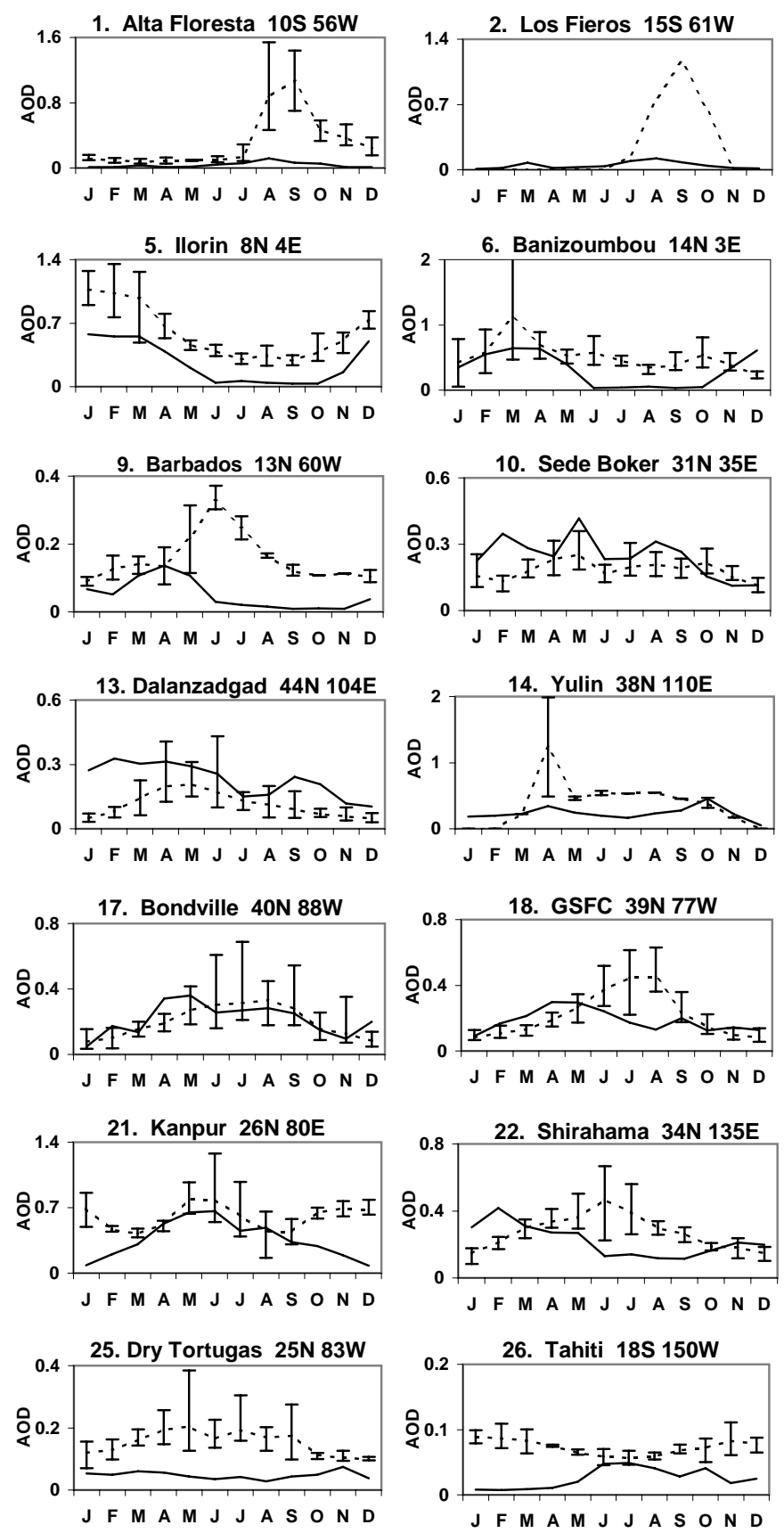
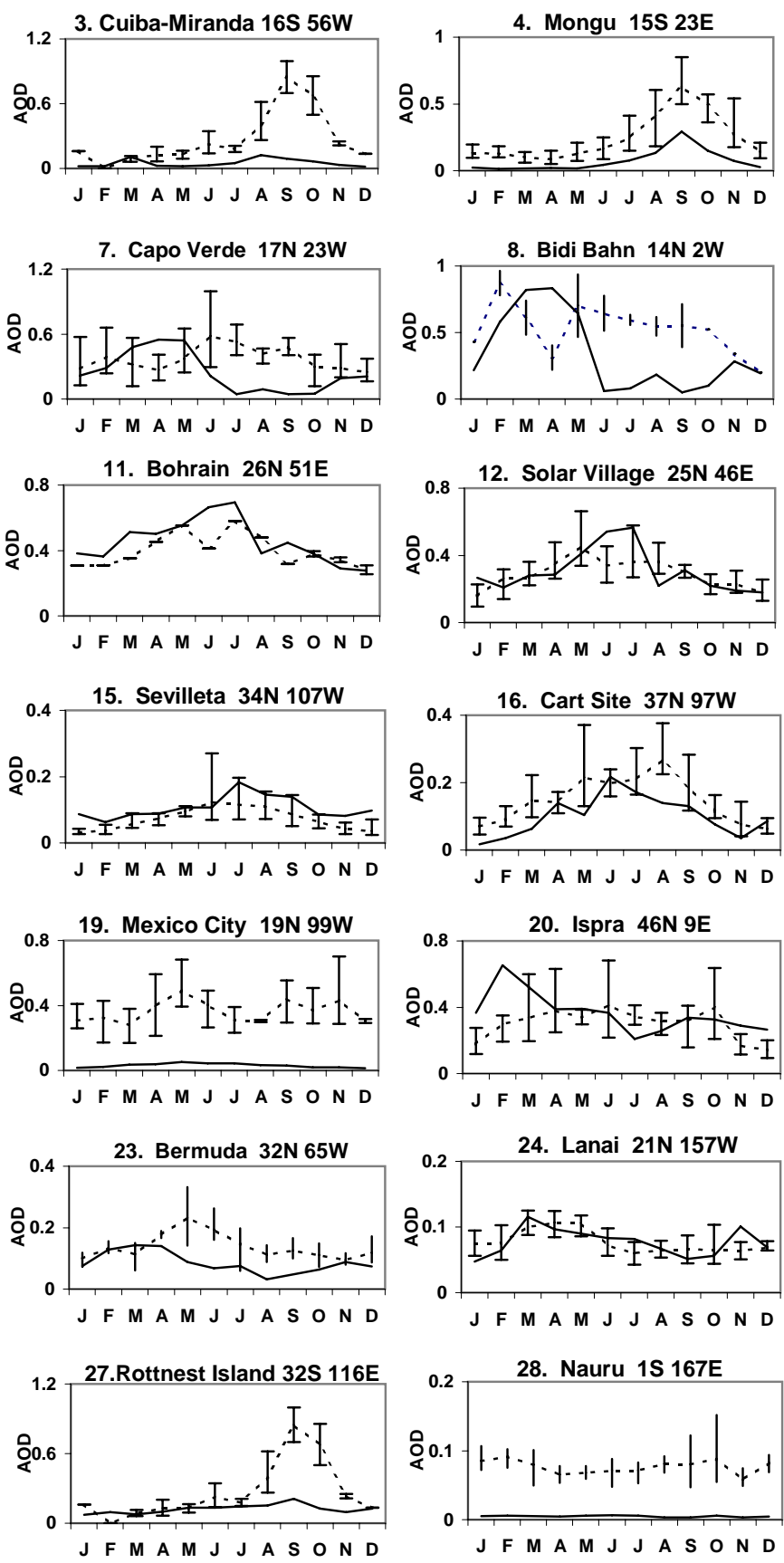

Fig. 7. A comparison of monthly averaged model AOD (solid lines) and AERONET AOD (dashed lines). The bars around the AERONET data denote minimum and maximum monthly average values in the multi-year measurements. The site numbers correspond to those in Table 3.

\section{Discussion}

Generally, the GISS-TOMAS evaluation of AOD against MODIS, MISR, and AERONET shows good agreement (within a factor of 2) with the best agreement occurring in polluted continental regions (high sulfate regions), dusty regions, and moderate sea-salt regions. One of polluted continental locations, Mexico City, is significantly underpredicted as shown in Fig. 6. This underprediction is very likely because the model grid size is too large to capture the unique topographical features of the Mexico City air basin. This underprediction is also found in other models (Kinne et al., 2003). The underprediction of AOD in dusty regions during June to October is illustrated in Figs. 2 and 7. This is due to low surface wind speeds that results in underestimation of mineral dust during summer and autumn (Lee et al., 2009). 

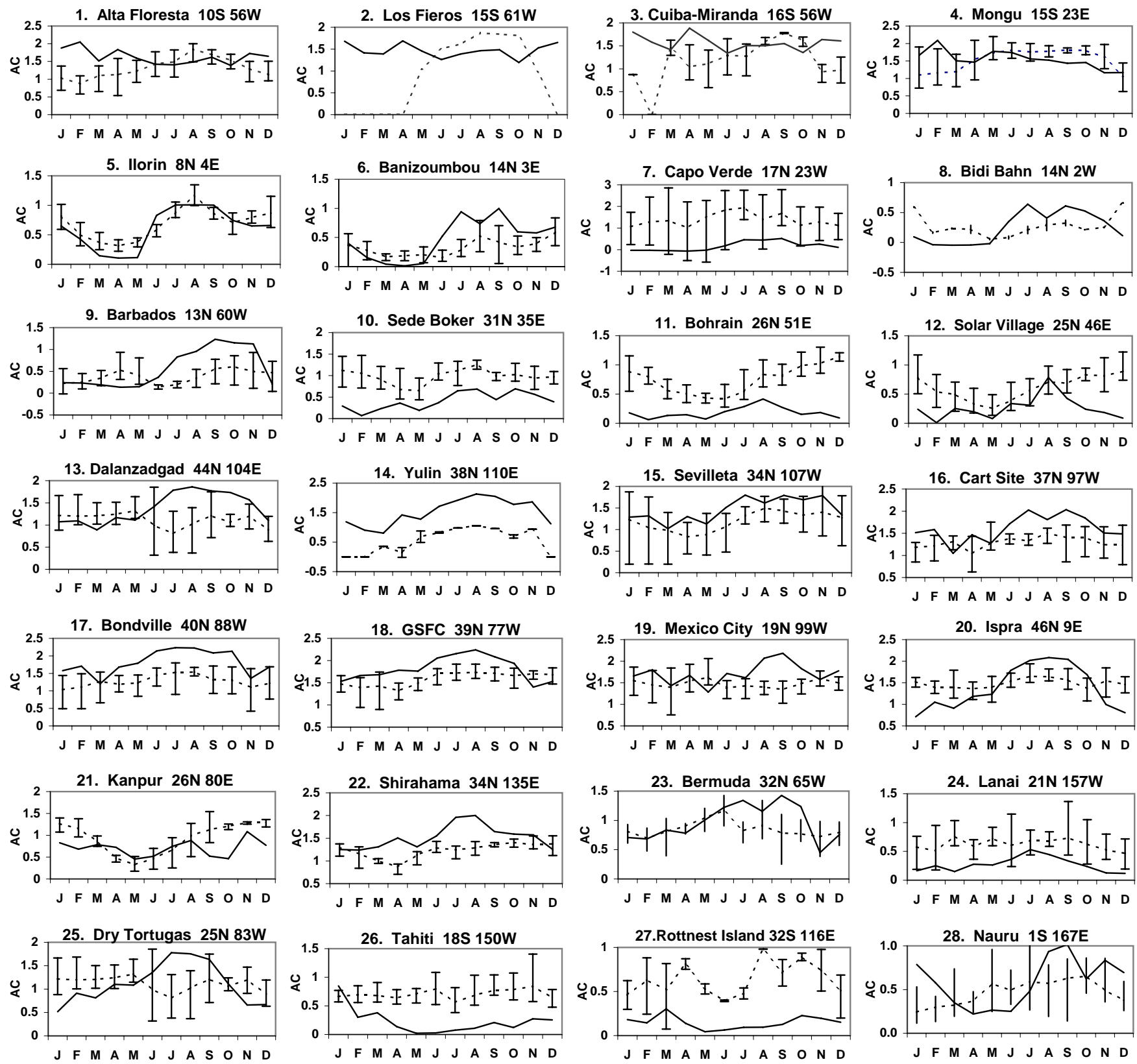

Fig. 8. Temporal distribution of AC (Angstrom coefficient) of the model and AERONET. The solid line is for the model prediction and the dashed line is for AERONET. The bars around the AERONET data denote minimum and maximum monthly average values in the multi-year measurements.

Significant underpredictions in AOD are found over the equatorial oceanic regions (e.g., Nauru, 2008), while significant overpredictions are found over high-latitude marine regions. To investigate this further, Fig. 9 shows a scatter plot of simulated and observed sea-salt surface mass concentrations from Savoie and Prospero (1977), divided into NH high latitude, SH high latitude, and near equatorial regions. In order to match the $\mathrm{PM}_{10}$ inlet of typical aerosol samplers in an environment with $80 \%$ relative humidity, similar to the procedure used by Guelle et al. (2001), predicted sea-salt mass is associated with particles smaller than $4 \mu \mathrm{m}$ dry diameter (Pierce and Adams, 2006). The model significantly underpredicts sea-salt mass concentrations at Nauru $\left(0.5^{\circ} \mathrm{S}\right.$ $\left.167^{\circ} \mathrm{E}\right)$ and Enewetak Atoll $\left(11.3^{\circ} \mathrm{N} 162.3^{\circ} \mathrm{E}\right)$, where the observed sea-salt mass concentrations are highest. In contrast, the model agrees well with observations at Fanning Island $\left(3.9^{\circ} \mathrm{N} 159.3^{\circ} \mathrm{W}\right)$, where the observed concentrations are moderate. The model's tendency to underpredict seasalt mass (and therefore AOD) in equatorial marine areas is mostly due to low biases in GISS GCM wind speeds that 
reduce sea-salt emissions (Pierce and Adams, 2006). In addition, a potential issue of heavy precipitation near the equator that causes low aerosol loading in GCM ModelE (Miller et al., 2006), with some of the same physics as the GISS GCM II', may partly explain the underprediction at the equator.

For high latitude, the model AOD substantially overpredicts observations. The clear-sky AOD from satellite is expected to be much lower than the all-sky AOD from our model at high latitudes. Figure 2 in Schmidt et al. (2006) shows AOD from the clear-sky and all-sky in GISS ModelE, and AOD in SH/NH high latitude is much higher in allsky due to the particle growth by water uptake at high relative humidity in cloudy-sky. In fact, the model high AOD is mostly contributed by aerosol-associated water mass. The average hydroscopic growth factor in $\mathrm{SH}$ high latitude $\left(50^{\circ} \mathrm{S}\right.$ to $65^{\circ} \mathrm{S}$ ), defined as the wet particle mass divided by the dry particle mass, is about 12 , corresponding to a relative humidity of $95 \%$. Even though the mass extinction efficiency decreases with particle size and is generally small in coarse mode, high sea-salt mass as well as water mass increases AOD significantly. As a lower bound on AOD, we also computed the dry AOD predicted by our model. The clearsky AOD will, of course, be greater due to water uptake by aerosols. At high latitudes, where the model AOD is a factor 3-5 times higher than satellite-retrieved AOD (shown Fig. 3), the model dry AOD is lower than observations by a factor of 2-3 (not shown). Performing a meaningful model-satellite comparison in this region is greatly complicated by several related challenges: difficulties in cloud-screening the satellite data, infrequent and possibly unrepresentative sampling, and determining the appropriate amount of aerosol water uptake in the model for comparison against satellite observations.

For NH high latitudes, the model sea-salt and mineral dust in Mace Head $\left(53^{\circ} \mathrm{N} 10^{\circ} \mathrm{W}\right)$ and Heimaey $\left(63^{\circ} \mathrm{N} 20^{\circ} \mathrm{W}\right)$ are underestimated, but the discrepancy is less than a factor of two, except the mineral dust in Heimaey $\left(63^{\circ} \mathrm{N} 20^{\circ} \mathrm{W}\right)$, which is underpredicted more than an order of magnitude. However, the model AOD is overpredicted by a factor of 2-3 compared to MISR data and a factor of 3-4 for the MODIS data: this difference between MISR and MODIS in high latitude could be due to cloud screening algorithms (Myhre et al., 2005). The overprediction of AOD in NH high latitudes may be mostly due to including cloudy-sky.

For SH high latitudes, Fig. 9 shows the overprediction of sea-salt mass by about a factor of 2.6 in Palmer Station $\left(65^{\circ} \mathrm{S} 64^{\circ} \mathrm{W}\right)$. Worse agreements are found at Marsh $\left(62^{\circ} \mathrm{S} 58^{\circ} \mathrm{W}\right)$ and Mawson $\left(68^{\circ} \mathrm{S} 62^{\circ} \mathrm{E}\right)$. The overprediction of sea-salt mass concentrations in SH high latitude regions may be mainly due to the emission scheme used. Figure 5 in Pierce and Adams (2006) presents four different seasalt emission schemes and the model simulation with Clarke et al. (2006) results in the overprediction of sea-salt mass concentration at Palmer Station; currently our model uses sea-salt other schemes. In fact, this leads to high AOD over

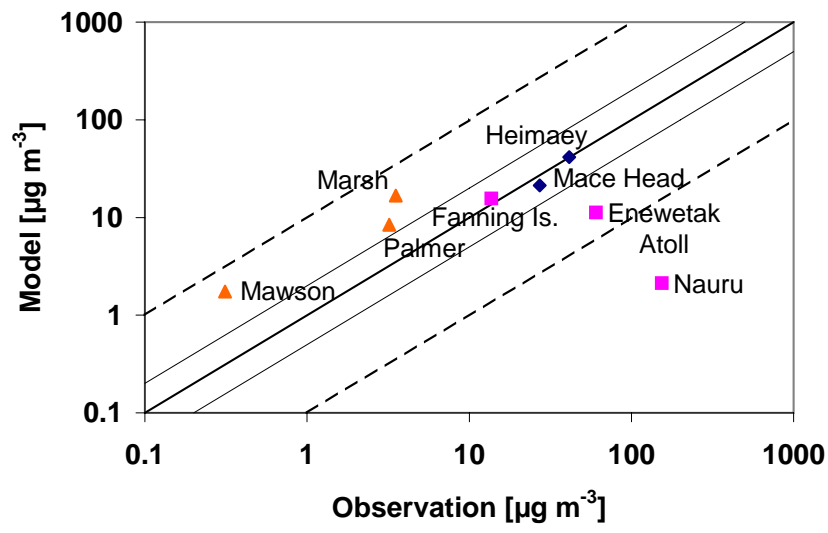

- $\mathrm{NH}$ high latitude $\square$ Near equator $\left(20^{\circ} \mathrm{S}-20^{\circ} \mathrm{N}\right) \triangle \mathrm{SH}$ high latitude

Fig. 9. Scatter plot of annually averaged surface mass concentrations of sea-salt predicted by the model and measurements in units of $\mu \mathrm{g} \mathrm{m}^{-3}$ at $273 \mathrm{~K}$ and $1013 \mathrm{hPa}$. Thick and thin solid lines are the 1:1 line and 2:1 lines, respectively. Dashed lines are 10:1 lines.

SH high latitude. AOD averaged from $40^{\circ} \mathrm{S}$ to $60^{\circ} \mathrm{S}$ using Martensson et al. (2003) and O'Dowd et al. (1997) are only $20 \%$ and $60 \%$ of AOD using Clarke emission, respectively. This comparison indicates that AOD at SH high latitudes is largely a function of sea-salt emission scheme. Given the focus on $\mathrm{CCN}$ in our model, the Clarke emission parameterization is chosen for its inclusion of ultrafine sea-salt particle emissions emission based on Clarke et al. (2006). Figure 6 in Pierce and Adams (2007) shows mass size distributions of various sea-salt emission schemes averaged over Southern Hemisphere (SH) high latitudes that are evaluated against Berner Impactor measurements. Unfortunately, the Berner Impactor is inefficient at collecting supermicron particles, which contribute the most mass. However, among seasalt emission schemes, the Clarke emissions indeed produce higher mass (noticeable for supermicron particles) compared to and because the resulting number size distributions compare well with observations. Unfortunately, the mass distribution with the Clarke scheme appears to contribute significantly to the AOD overestimation.

A minor factor contributing to the AOD over-prediction in these areas may stem from a planetary boundary layer that is somewhat too deep. The planetary boundary layer obtained from MERRA (Modern Era Retrospective-analysis for Research and Applications), a NASA reanalysis for the satellite era using a major new version of the Goddard Earth Observing System Data Assimilation System Version 5 (GEOS-5), in these regions is typically $\sim 600 \mathrm{~m}$, corresponding approximately to our lowest model layer ( 984 to $934 \mathrm{hPa}$ ). Approximately half of the column sea-salt in our model remains in this lowest layer while $\sim 25 \%$ and $\sim 15 \%$ are found in the second (934 to $854 \mathrm{hPa}$ ) and third ( 854 to $720 \mathrm{hPa}$ ) layers respectively. The presence of sea-salt in these layers suggests 
a sea-salt layer that is too deep, but the effect on model AOD is unlikely to be greater than a factor of 2 and, therefore, smaller than the issues discussed above.

The model underpredicted AOD in biomass burning regions compared to both AERONET and satellite measurements. To investigate any problems associated with that inventory in biomass burning regions, two additional biomass burning emission inventories were tested: the Global Fire Emission Database (GFED) emission year 2000 (van der Werf et al., 2004) and an emission inventory used by the IPCC Third Assessment Report (IPCC, 2001), which is based on Penner et al. (1993) and Liousse et al. (1996) (see more detailed description in Pierce et al., 2007). Using the same OM:OC ratio assumption as our model, the GFED emission inventory gives similar total $\mathrm{OM}$ emission rate as BOND emission, but the seasonality of predicted AOD in South America using GFED emissions is improved. The IPCC inventory has higher emissions than the BOND inventory ( $54 \mathrm{Tg} \mathrm{yr}^{-1}$ compared to $45 \mathrm{Tg} \mathrm{yr}^{-1}$ for primary OM and 5.7 $\mathrm{Tg} \mathrm{yr}^{-1}$ compared to $3.3 \mathrm{Tg} \mathrm{yr}^{-1}$ for EC). Using the IPCC inventory, the model's AOD prediction in South American sites $(1,2,3)$ is improved (not shown), but it is still underestimated by a factor of 5 , as compared to a factor of 7.5 with the original Bond et al. (2004) emissions. In summary, our model underpredicts AOD in South America with any of the commonly accepted biomass burning emission inventories.

Biomass burning emission has large spatial and temporal variations, and the year 2000 GFED emissions are the lowest year in the 1997 to 2006 time period (van der Werf et al., 2006). Use of relatively low biomass burning emissions in this work means that we expect a certain amount of underprediction compared to multi-year AERONET AOD (from 1999 to 2005, see Table 3 for details regarding time period). In Kinne et al. (2006), global models based on the GFED emission year 2000 have generally underpredicted AOD over the tropical biomass burning regions even when compared to AERONET AOD observed in the same year. AERONET AOD over Abracos Hill $\left(11^{\circ} \mathrm{S} 62^{\circ} \mathrm{W}\right)$ in South America is approximately $0.5-0.6$ in August and September, while AOD averaged among participating global models is around $0.3-0.4$ and the lowest AOD is around 0.1-0.2. Our model AOD is 0.12 (August) and 0.17 (September). Global models have generally underestimated AOD over biomass burning regions. Our tendency to underpredict AOD in biomass burning regions is similar to some other global models but towards the low end of the range.

In our model, this general tendency to underestimate biomass burning AOD values seems to be related to wet deposition, although it appears that the bias stems from the wet deposition parameterization rather than errors in precipitation. Wet deposition is a major removal process for the carbonaceous aerosols, but its lifetime is expected to be long during the typical dry season, in August and September, when the biomass burning emission reaches to the maximum. However, the model-predicted wet deposition lifetime over the AERONET sites in South America is $\sim 16$ days for August, $\sim 5$ days for September, and $\sim 4$ days for October and November. For comparison, our global mean aerosol OM lifetime with respect to wet deposition is $\sim 5$ days. For September and October, corresponding to the mid and later biomass burning and dry seasons, our model-predicted aerosol wet deposition lifetimes of $\sim 5$ days (similar to the global average) seem too short. However, when comparing model precipitation to monthly average precipitation measured by the TRMM satellite (obtained at http://agdisc.gsfc.nasa.gov/Giovanni/aovas) from August to November in 2002, no clear sign of model overprediction is found. Therefore, our model appears to be wet depositing organic aerosol too quickly in these areas despite having reasonable precipitation rate. Future work should investigate errors in precipitation distribution and frequency as well as aerosol scavenging efficiency to understand the source of these biases.

The predicted organic and elemental carbon concentrations from the simulation with the Bond emission inventory are compared to the Large Scale Biosphere-Atmosphere Experiment in Amazonia - Smoke, Aerosols, Clouds, Rainfall, and Climate (LBA-SMOCC) experiment 2002, which was conducted in Rondônia $\left(10^{\circ} \mathrm{S} 62^{\circ} \mathrm{W}\right)$, Brazil during September to mid-November 2002 (Decesari et al., 2006). The model fine OC concentration $\left(5.5 \mu \mathrm{g} \mathrm{m}^{-3}\right)$ and EC concentration $\left(0.9 \mu \mathrm{g} \mathrm{m}^{-3}\right)$ during the dry season are $17 \%$ and $80 \%$ of the observation $\left(31.6 \mu \mathrm{g} \mathrm{m}^{-3}\right.$ for OC and $1.1 \mu \mathrm{g} \mathrm{m}^{-3}$ for EC), respectively. For the simulations with the GFED emission year 2000, the model fine OC concentration is slightly higher but only $26 \%$ of the observation. Although this is a rough comparison, it links the underprediction of AOD with the underprediction of surface mass OM concentration during the dry season.

In general, model $\mathrm{AC}$ reflects the dominate aerosol type in a region and tends to agree with AERONET AC. Despite poor AOD predictions in biomass burning regions, $\mathrm{AC}$ is well predicted. Dusty sites $(7,10,11,12)$ underpredict AC compared to AERONET. The dust model in the GISS-TOMAS model produces few sub-micron dust particles compared to limited available observations (Lee et al., 2009), which may explain the lower AC. Model AC in Barbados and Bidi Bahn is overpredicted from June to October, which can be explained by an underprediction of mineral dust mass concentration (Lee et al., 2009).

\section{Summary and conclusions}

A module for calculating AOD is developed for the evaluation of the GISS-TOMAS global aerosol microphysics model, and model predictions are evaluated against remote sensing data from MODIS, MISR, and AERONET. Generally, evaluations against satellite-based and AERONET AOD 
lead to similar conclusions. However, the global coverage of satellite data greatly increases our confidence that these conclusions are true for large regions and are not significantly dependent on local factors specific to AERONET sites. The model AOD agrees with AOD retrieved from satellites within a factor of two over polluted continental, dusty, and moderate sea-salt regions. Similarly, the AOD evaluation against AERONET agrees generally within a factor of two over polluted continental locations (except Mexico City), dusty, and remote oceanic sites except equatorial oceanic sites.

In equatorial marine regions, the model AOD is significantly underpredicted compared remote sensing measurements. The low AOD results from an underprediction in seasalt concentrations, which in turn result from wind speeds in the GCM. High precipitation rates may also play a role.

There are large errors ( $\sim$ a factor of 5$)$ over high latitude marine regions in both the Northern and Southern hemispheres. Overprediction of AOD in high latitude is likely due to inclusion of cloudy-sky in the model AOD calculation compared to satellites that sample clear sky only. However, in SH high latitudes, the model overprediction is also partly due to high sea-salt emission from the emission scheme used in the model. It is worthy to note that satellite retrievals over high latitude have limitations such as larger differences in AOD retrieved among satellites possibly due to cloud screening algorithms, difficulty in cloud screening (distinguish between cloud droplets from swelling aerosols by water uptake), and biases toward sampling clear sky conditions. In this regard, it is difficult to evaluate the model AOD in high latitude with the satellite-based AOD.

AOD in biomass burning regions is generally underpredicted in global models. However, during the dry season over South America, our model tends to underpredict AOD more severely, by a factor of 4-5 similar to errors observed in a few other global models. Compared to the surface-level OC and EC concentrations from LBA-SMOCC 2002 experiment data, the model shows significant underpredictions of OC concentration during the dry season. The underprediction is observed with all commonly used global emissions inventories. More severely underprediction of AOD compared to other global model might be due to short wet deposition lifetime during the dry season. However, further investigation is needed to find errors in precipitation distribution and frequency as well as aerosol scavenging efficiency to understand the source of these biases. Since global models have generally underestimated AOD over biomass burning regions, this might indicate that current biomass burning emissions inventories may be too low.
Acknowledgements. We acknowledge the MODIS and MISR mission scientists and associated NASA personnel for the production of the data used in this work. We thank the PI investigators and their staff (Brent Holben, Didier Tanré, Rick Wagener, Ramesh P. Singh, Arnon Karnieli, Rachel T. Pinker, Naif AlAbbadi, Giuseppe Zibordi, Doug Moore, Kenneth J. Voss, Bernadette Chatenet, Xiao-Ye Zhang, and Laurent Gomes) for establishing and maintaining the 28 sites used in this work and for providing the ground-based aerosol data used in this work.

Edited by: A. Nenes

\section{References}

Abdou, W. A., Diner, D. J., Martonchik, J. V., Bruegge, C. J., Kahn, R. A., Gaitley, B. J., Crean, K. A., Remer, L. A., and Holben, B.: Comparison of coincident Multiangle Imaging Spectroradiometer and Moderate Resolution Imaging Spectroradiometer aerosol optical depths over land and ocean scenes containing Aerosol Robotic Network sites, J. Geophys. Res.-Atmos., 110(D10), D10S07, doi:10.1029/2004JD004693, 2005.

Adams, P. J. and Seinfeld, J. H.: Predicting global aerosol size distributions in general circulation models, J. Geophys. Res.Atmos., 107, 4370, doi:10.1029/2001JD001010, 2002.

Bond, T. C., Streets, D. G., Yarber, K. F., Nelson, S. M., Woo, J. H. and Klimont, Z.: A technology-based global inventory of black and organic carbon emissions from combustion, J. Geophys. Res.-Atmos., 109, D14203, doi:10.1029/2003JD003697, 2004.

Bond, T. C. and Bergstrom, R. W.: Light absorption by carbonaceous particles: An investigative review, Aerosol Science and Technology, 40(1), 27-67, 2006.

Brennan, J. I., Kaufman, Y. J., Koren, I., and Li, R. R.: Aerosolcloud interaction-misclassification of MODIS clouds in heavy aerosol, Ieee Transactions on Geoscience and Remote Sensing, 43(4), 911-915, 2005.

Clarke, A. D., Owens, S. R., and Zhou, J. C.: An ultrafine seasalt flux from breaking waves: Implications for cloud condensation nuclei in the remote marine atmosphere, J. Geophys. Res.Atmos., 111, D06202, doi:10.1029/2005JD006565, 2006.

Decesari, S., Fuzzi, S., Facchini, M. C., Mircea, M., Emblico, L., Cavalli, F., Maenhaut, W., Chi, X., Schkolnik, G., Falkovich, A., Rudich, Y., Claeys, M., Pashynska, V., Vas, G., Kourtchev, I., Vermeylen, R., Hoffer, A., Andreae, M. O., Tagliavini, E., Moretti, F., and Artaxo, P.: Characterization of the organic composition of aerosols from Rondnia, Brazil, during the LBASMOCC 2002 experiment and its representation through model compounds, Atmos. Chem. Phys., 6, 375-402, 2006, http://www.atmos-chem-phys.net/6/375/2006/.

Del Genio, A. D. and Yao, M. S.: Efficient cumulus parameterization for long-term climate studies: The GISS scheme, in The Representation of Cumulus Convection in Numerical Models, American Meteorological Society, Boston, Mass., 1993.

Del Genio, A. D., Yao, M. S., Kovari, W., and Lo, K. K. W.: A prognostic cloud water parameterization for global climate models, J. Climate, 9(2), 270-304, 1996.

Di Girolamo, L. and Wilson, M. J.: A first look at band-differenced angular signatures for cloud detection from MISR, Ieee Trans- 
actions on Geoscience and Remote Sensing, 41(7), 1730-1734, 2003.

Dick, W. D., Saxena, P., and McMurry, P. H.: Estimation of water uptake by organic compounds in submicron aerosols measured during the Southeastern Aerosol and Visibility Study, J. Geophys. Res.-Atmos., 105(D1), 1471-1479, 2000.

Diner, D. J., Beckert, J. C., Reilly, T. H., Bruegge, C. J., Conel, J. E., Kahn, R. A., Martonchik, J. V., Ackerman, T. P., Davies, R., Gerstl, S. A. W., Gordon, H. R., Muller, J. P., Myneni, R. B., Sellers, P. J., Pinty, B. and Verstraete, M. M.: Multi-angle Imaging SpectroRadiometer (MISR) - Instrument description and experiment overview, Ieee Transactions on Geoscience and Remote Sensing, 36(4), 1072-1087, 1998.

Dubovik, O., Smirnov, A., Holben, B. N., King, M. D., Kaufman, Y. J., Eck, T. F., and Slutsker, I.: Accuracy assessments of aerosol optical properties retrieved from Aerosol Robotic Network (AERONET) Sun and sky radiance measurements, J. Geophys. Res.-Atmos., 105(D8), 9791-9806, 2000.

Forster, P., Ramaswamy, V., Artaxo, P., Berntsen, T., Betts, R., Fahey, D. W., Haywood, J., Lean, J., Lowe, D. C., Myhre, G., Nganga, J., Prinn, R., Raga, G., Schulz, M., and Dorland, R. V.: Changes in Atmospheric Constituents and in Radiative Forcing, Cambridge University Press, Cambridge, United Kingdom and New York, NY, USA, 2007.

Gates, W. L., Boyle, J. S., Covey, C., Dease, C. G., Doutriaux, C. M., Drach, R. S., Fiorino, M., Gleckler, P. J., Hnilo, J. J., Marlais, S. M., Phillips, T. J., Potter, G. L., Santer, B. D., Sperber, K. R., Taylor, K. E., and Williams, D. N.: An overview of the results of the Atmospheric Model Intercomparison Project (AMIP I), B. Am. Meteorol. Soc., 80(1), 29-55, 1999.

Guelle, W., Schulz, M., Balkanski, Y., and Dentener, F.: Influence of the source formulation on modeling the atmospheric global distribution of sea salt aerosol, J. Geophys. Res.-Atmos., 106(D21), 27509-27524, 2001.

Hale, G. M. and Querry, M. R.: Optical-Constants of Water in 200$\mathrm{Nm}$ to 200-Mum Wavelength Region, Appl. Optics, 12(3), 555$563,1973$.

Hansen, J., Russell, G., Rind, D., Stone, P., Lacis, A., Lebedeff, S., Ruedy, R., and Travis, L.: Efficient 3-Dimensional Global-Models for Climate Studies - Model-I and Model-Ii, Mon. Weather Rev., 111(4), 609-662, 1983.

Hansen, J., Sato, M., Ruedy, R., Nazarenko, L., Lacis, A., Schmidt, G. A., Russell, G., Aleinov, I., Bauer, M., Bauer, S., Bell, N., Cairns, B., Canuto, V., Chandler, M., Cheng, Y., Del Genio, A., Faluvegi, G., Fleming, E., Friend, A., Hall, T., Jackman, C., Kelley, M., Kiang, N., Koch, D., Lean, J., Lerner, J., Lo, K., Menon, S., Miller, R., Minnis, P., Novakov, T., Oinas, V., Perlwitz, J., Rind, D., Romanou, A., Shindell, D., Stone, P., Sun, S., Tausnev, N., Thresher, D., Wielicki, B., Wong, T., Yao, M., and Zhang, S.: Efficacy of climate forcings, J. Geophys. Res.Atmos., 110(D18), D18104, doi:10.1029/2005JD005776, 2005.

Hartke, G. J. and Rind, D.: Improved surface and boundary layer models for the Goddard Institute for Space Studies general circulation model, J. Geophys. Res.-Atmos., 102(D14), 16407$16422,1997$.

Hess, M., Koepke, P., and Schult, I.: Optical properties of aerosols and clouds: The software package OPAC, B. Am. Meteorol. Soc., 79(5), 831-844, 1998.

Holben, B. N., Eck, T. F., Slutsker, I., Tanre, D., Buis, J. P., Set- zer, A., Vermote, E., Reagan, J. A., Kaufman, Y. J., Nakajima, T., Lavenu, F., Jankowiak, I., and Smirnov, A.: AERONET -A federated instrument network and data archive for aerosol characterization, Remote Sens. Environ., 66(1), 1-16, 1998.

Holben, B. N., Tanre, D., Smirnov, A., Eck, T. F., Slutsker, I., Abuhassan, N., Newcomb, W. W., Schafer, J. S., Chatenet, B., Lavenu, F., Kaufman, Y. J., Castle, J. V., Setzer, A., Markham, B., Clark, D., Frouin, R., Halthore, R., Karneli, A., O’Neill, N. T., Pietras, C., Pinker, R. T., Voss, K., and Zibordi, G.: An emerging ground-based aerosol climatology: Aerosol optical depth from AERONET, J. Geophys. Res.-Atmos., 106(D11), 1206712097, 2001.

IPCC: Intergovernmental Panel on Climate Change 2001: The Scientific Basis - Technical Summary, 2001.

Jin, Y. F., Gao, F., Schaaf, C. B., Li, X. W., Strahler, A. H., Bruegge, C. J., and Martonchik, J. V.: Improving MODIS surface BRDF/Albedo retrieval with MISR multiangle observations, IEEE Trans. Geosci. Remote Sensing, 40(7), 1593-1604, 2002.

Kahn, R. A., Ogren, J. A., Ackerman, T. P., Bosenberg, J., Charlson, R. J., Diner, D. J., Holben, B. N., Menzies, R. T., Miller, M. A., and Seinfeld, J. H.: Aerosol data sources and their roles within PARAGON, B. Am. Meteorol. Soc., 85(10), 1511-1522, 2004.

Kahn, R. A., Gaitley, B. J., Martonchik, J. V., Diner, D. J., Crean, K. A., and Holben, B.: Multiangle Imaging Spectroradiometer (MISR) global aerosol optical depth validation based on 2 years of coincident Aerosol Robotic Network (AERONET) observations, J. Geophys. Res.-Atmos., 110(D10), D10S04, doi:10.1029/2004JD004706, 2005.

Kerminen, V. M., Anttila, T., Lehtinen, K. E. J., and Kulmala, M.: Parameterization for atmospheric new-particle formation: Application to a system involving sulfuric acid and condensable watersoluble organic vapors, Aerosol Sci. Technol., 38(10), 10011008, 2004.

Kinne, S., Lohmann, U., Feichter, J., Schulz, M., Timmreck, C., Ghan, S., Easter, R., Chin, M., Ginoux, P., Takemura, T., Tegen, I., Koch, D., Herzog, M., Penner, J., Pitari, G., Holben, B., Eck, T., Smirnov, A., Dubovik, O., Slutsker, I., Tanre, D., Torres, O., Mishchenko, M., Geogdzhayev, I., Chu, D. A., and Kaufman, Y.: Monthly averages of aerosol properties: A global comparison among models, satellite data, and AERONET ground data, J. Geophys. Res.-Atmos., 108(D20), 4634, doi:10.1029/2001JD001253, 2003.

Kinne, S., Schulz, M., Textor, C., Guibert, S., Balkanski, Y., Bauer, S. E., Berntsen, T., Berglen, T. F., Boucher, O., Chin, M., Collins, W., Dentener, F., Diehl, T., Easter, R., Feichter, J., Fillmore, D., Ghan, S., Ginoux, P., Gong, S., Grini, A., Hendricks, J., Herzog, M., Horowitz, L., Isaksen, I., Iversen, T., Kirkevåg, A., Kloster, S., Koch, D., Kristjansson, J. E., Krol, M., Lauer, A., Lamarque, J. F., Lesins, G., Liu, X., Lohmann, U., Montanaro, V., Myhre, G., Penner, J., Pitari, G., Reddy, S., Seland, O., Stier, P., Takemura, T., and Tie, X.: An AeroCom initial assessment - optical properties in aerosol component modules of global models, Atmos. Chem. Phys., 6, 1815-1834, 2006, http://www.atmos-chem-phys.net/6/1815/2006/.

Koren, I., Remer, L. A., Kaufman, Y. J., Rudich, Y., and Martins, J. V.: On the twilight zone between clouds and aerosols, Geophys. Res. Lett., 34(8), L08805, doi:10.1029/2007GL029253, 2007.

Lee, Y. H., Chen, K., and Adams, P. J.: Development of a global model of mineral dust aerosol microphysics, Atmos. Chem. 
Phys., 9, 2441-2458, 2009,

http://www.atmos-chem-phys.net/9/2441/2009/.

Li, R. R., Remer, L., Kaufman, Y. J., Mattoo, S., Gao, B. C., and Vermote, E.: Snow and ice mask for the MODIS aerosol products, IEEE Geosci. Remote Sens. Lett., 2(3), 306-310, 2005.

Liousse, C., Penner, J. E., Chuang, C., Walton, J. J., Eddleman, H., and Cachier, H.: A global three-dimensional model study of carbonaceous aerosols, J. Geophys. Res.-Atmos., 101(D14), 19411-19432, 1996.

Liu, L., Lacis, A. A., Carlson, B. E., Mishchenko, M. I., and Cairns, B.: Assessing Goddard Institute for Space Studies ModelE aerosol climatology using satellite and ground-based measurements: A comparison study, J. Geophys. Res.-Atmos., 111(D20), D20212, doi:10.1029/2006JD007334, 2006.

Liu, Y., Sarnat, J. A., Coull, B. A., Koutrakis, P., and Jacob, D. J.: Validation of multiangle imaging spectroradiometer (MISR) aerosol optical thickness measurements using aerosol robotic network (AERONET) observations over the contiguous United States, J. Geophys. Res.-Atmos., 109(D6), D06205, doi:10.1029/2003JD003981, 2004.

Martensson, E. M., Nilsson, E. D., de Leeuw, G., Cohen, L. H., and Hansson, H. C.: Laboratory simulations and parameterization of the primary marine aerosol production, J. Geophys. Res.-Atmos., 108(D9), 4297, doi:10.1029/2002JD002263, 2003.

Miller, R. L., Cakmur, R. V., Perlwitz, J., Geogdzhayev, I. V., Ginoux, P., Koch, D., Kohfeld, K. E., Prigent, C., Ruedy, R., Schmidt, G. A., and Tegen, I.: Mineral dust aerosols in the NASA goddard institute for Space Sciences ModelE atmospheric general circulation model, J. Geophys. Res.-Atmos., 111, D06208, doi:10.1029/2005JD005796, 2006.

Myhre, G., Stordal, F., Johnsrud, M., Diner, D. J., Geogdzhayev, I. V., Haywood, J. M., Holben, B. N., Holzer-Popp, T., Ignatov, A., Kahn, R. A., Kaufman, Y. J., Loeb, N., Martonchik, J. V., Mishchenko, M. I., Nalli, N. R., Remer, L. A., SchroedterHomscheidt, M., Tanré, D., Torres, O., and Wang, M.: Intercomparison of satellite retrieved aerosol optical depth over ocean during the period September 1997 to December 2000, Atmos. Chem. Phys., 5, 1697-1719, 2005,

http://www.atmos-chem-phys.net/5/1697/2005/.

Nenes, A., Pandis, S. N., and Pilinis, C.: ISORROPIA: A new thermodynamic equilibrium model for multiphase multicomponent inorganic aerosols, Aquatic Geochemistry, 4(1), 123-152, 1998.

Odowd, C. D., Smith, M. H., Consterdine, I. E., and Lowe, J. A.: Marine aerosol, sea-salt, and the marine sulphur cycle: A short review, Atmos. Environ., 31(1), 73-80, 1997.

Penner, J. E., Eddleman, H., and Novakov, T.: Towards the Development of a Global Inventory for Black Carbon Emissions, Atmos. Environ., 27(8), 1277-1295, 1993.

Pierce, J. R. and Adams, P. J.: Global evaluation of $\mathrm{CCN}$ formation by direct emission of sea salt and growth of ultrafine sea salt, J. Geophys. Res.-Atmos., 111, D06203, doi:10.1029/2005JD006186, 2006.

Pierce, J. R., Chen, K., and Adams, P. J.: Contribution of primary carbonaceous aerosol to cloud condensation nuclei: processes and uncertainties evaluated with a global aerosol microphysics model, Atmos. Chem. Phys., 7, 5447-5466, 2007. http://www.atmos-chem-phys.net/7/5447/2007/.

Pierce, J. R. and Adams, P. J.: Uncertainty in global CCN concentrations from uncertain aerosol nucleation and primary emission rates, Atmos. Chem. Phys., 9, 1339-1356, 2009a,

http://www.atmos-chem-phys.net/9/1339/2009/.

Pierce, J. R. and Adams, P. J.: A Computationally Efficient Aerosol Nucleation/Condensation Method: Pseudo-Steady-State Sulfuric Acid, Aerosol Sci. Technol., 43(3), 216-226, $2009 \mathrm{~b}$.

Pierce, J. R., Theodoritsi, G., Adams, P. J., and Pandis, S. N.: Parameterization of the effect of sub-grid scale aerosol dynamics on aerosol number emission rates, J. Aerosol Sci., 40(5), 385-393, 2009.

Prather, M. J.: Numerical Advection by Conservation of 2nd-Order Moments, J. Geophys. Res.-Atmos., 91(D6), 6671-6681, 1986.

Redemann, J., Zhang, Q., Russell, P. B., Livingston, J. M., and Remer, L. A.: Case studies of aerosol remote sensing in the vicinity of clouds, J. Geophys. Res.-Atmos., 114, D06209, doi:10.1029/2008JD010774, 2009.

Remer, L. A., Kleidman, R. G., Levy, R. C., Kaufman, Y. J., Tanre, D., Mattoo, S., Martins, J. V., Ichoku, C., Koren, I., Yu, H. B., and Holben, B. N.: Global aerosol climatology from the MODIS satellite sensors, J. Geophys. Res.-Atmos., 113(D14), D14S07, doi:10.1029/2007JD009661, 2008.

Rosenzweig, C. and Abramopoulos, F.: Land-surface model development for the GISS GCM, J. Climate, 10(8), 2040-2054, 1997.

Savoie, D. L. and Prospero, J. M.: Aerosol Concentration Statistics for Northern Tropical Atlantic, J. Geophys. Res.-Oceans and Atmospheres, 82(37), 5954-5964, 1977.

Schmidt, G. A., Ruedy, R., Hansen, J. E., Aleinov, I., Bell, N., Bauer, M., Bauer, S., Cairns, B., Canuto, V., Cheng, Y., Del Genio, A., Faluvegi, G., Friend, A. D., Hall, T. M., Hu, Y. Y., Kelley, M., Kiang, N. Y., Koch, D., Lacis, A. A., Lerner, J., Lo, K. K., Miller, R. L., Nazarenko, L., Oinas, V., Perlwitz, J., Rind, D., Romanou, A., Russell, G. L., Sato, M., Shindell, D. T., Stone, P. H., Sun, S., Tausnev, N., Thresher, D., and Yao, M. S.: Present-day atmospheric simulations using GISS ModelE: Comparison to in situ, satellite, and reanalysis data, J. Climate, 19(2), 153-192, 2006.

Schulz, M., Textor, C., Kinne, S., Balkanski, Y., Bauer, S., Berntsen, T., Berglen, T., Boucher, O., Dentener, F., Guibert, S., Isaksen, I. S. A., Iversen, T., Koch, D., Kirkevg, A., Liu, X., Montanaro, V., Myhre, G., Penner, J. E., Pitari, G., Reddy, S., Seland, Ø., Stier, P., and Takemura, T.: Radiative forcing by aerosols as derived from the AeroCom present-day and pre-industrial simulations, Atmos. Chem. Phys., 6, 5225-5246, 2006, http://www.atmos-chem-phys.net/6/5225/2006/.

Shettle, E. P. and Fenn, R. W.: Models of the aerosols of the loweratmosphere and the effects of humidity variations on their optical properties, Air Force Geoph. Lab., Massachusetts, 1979.

Stier, P., Feichter, J., Kinne, S., Kloster, S., Vignati, E., Wilson, J., Ganzeveld, L., Tegen, I., Werner, M., Balkanski, Y., Schulz, M., Boucher, O., Minikin, A., and Petzold, A.: The aerosolclimate model ECHAM5-HAM, Atmos. Chem. Phys., 5, 11251156, 2005, http://www.atmos-chem-phys.net/5/1125/2005/.

Tang, I. N.: Chemical and size effects of hygroscopic aerosols on light scattering coefficients, J. Geophys. Res.-Atmos., 101(D14), 19245-19250, 1996.

Tegen, I. and Fung, I.: Modeling of Mineral Dust in the Atmosphere - Sources, Transport, and Optical-Thickness, J. Geophys. Res.Atmos., 99(D11), 22897-22914, 1994. 
Torres, O., Bhartia, P. K., Herman, J. R., Sinyuk, A., Ginoux, P. and Holben, B.: A long-term record of aerosol optical depth from TOMS observations and comparison to AERONET measurements, J. Atmos. Sci., 59(3), 398-413, 2002.

Twohy, C. H., Coakley, J. A., and Tahnk, W. R.: Effect of changes in relative humidity on aerosol scattering near clouds, J. Geophys. Res.-Atmos., 114, D05205, doi:10.1029/2008JD010991, 2009. van der Werf, G. R., Randerson, J. T., Collatz, G. J., Giglio, L., Kasibhatla, P. S., Arellano, A. F., Olsen, S. C., and Kasischke, E. S.: Continental-scale partitioning of fire emissions during the 1997 to 2001 El Nino/La Nina period, Science, 303(5654), 7376, 2004. van der Werf, G. R., Randerson, J. T., Giglio, L., Collatz, G. J., Kasibhatla, P. S., and Arellano Jr., A. F.: Interannual variability in global biomass burning emissions from 1997 to 2004, Atmos. Chem. Phys., 6, 3423-3441, 2006,

http://www.atmos-chem-phys.net/6/3423/2006/. 